\title{
Neo-Nazi Nationalism
}

\author{
Amy Cooter* \\ University of Michigan
}

\begin{abstract}
In an effort to understand how supremacists may respond to future socio-political events, this article examines how White Aryan Resistance (WAR), as a major player in the White Supremacist Movement (WSM), conceptualises nationalism and who qualifies as a 'real' American. I use discourse analysis on two year's worth of WAR newsletters: twelve monthly issues before the September 11, 2001 terrorist attacks and twelve issues after this date. Only partial support is found for outcomes that the existing nationalism literature would predict, suggesting that those who research the right-wing must better understand the WSM's sense of status loss to adequately predict future violent action from these groups. I show that WAR did not increasingly target Arabs after the attacks, which may have enhanced their membership and mobilisation efforts, but that this decision was a rational response in the context of status threats and limited movement resources.
\end{abstract}

\section{Introduction}

Nationalism generally refers to feelings of belonging that individuals have toward their national groups, which may be demarcated by physical boundaries of a state or by imagined boundaries of ethnicity, culture, or religion. I examine how an important component of the White Supremacist Movement (WSM) - White Aryan Resistance (WAR) - conceptualises nationalism and how this understanding influenced their response to the terror attacks of September 11, 2001 (9/11). Understanding WAR's version of nationalism helps link previous literatures on nationalism and white supremacy. Analysing WAR's response to 9/11 allows us to better predict when unpopular movements may mobilise or expand following events of national importance. This may additionally help us understand why supremacist groups choose particular targets for violent activity, which is useful information for law enforcement agencies seeking to prevent such violence.

\footnotetext{
* Amy Cooter is a sociology Ph.D. candidate at the University of Michigan and is a recipient of a National Science Foundation Graduate Research Fellowship. Her research interests include the examination of how conservative movements and organisations navigate the broader socio-political arena. She is currently studying the modern militia movement.
} 


\section{The White Supremacist Movement}

It is important to note that organised white supremacist activity may be conceptualised as part of a larger social movement. Although some researchers resist using the term 'movement' to refer to 'regressive' or right-wing collective behaviour, Kathleen Blee (2003), Jessie Daniels (1997), and Abby Ferber (1999), three of the foremost authors on white racist groups, are among those acknowledging a White Supremacist Movement. ${ }^{1}$ Organised white supremacist activity should be considered a social movement for the following reasons. Definitions of social movements typically resemble Jeff Goodwin and James Jasper's statement that, 'Social movements are conscious, concerted, and sustained efforts by ordinary people to change some aspect of their society by using extra-institutional means' (Goodwin and Jasper 2009:3). Social movements have some continuity over time, and some researchers may be uncomfortable with the WSM's relatively consistently low level of activity. Low activity is not equivalent to no activity, particularly when white supremacist activity spikes in response to major social change like the election of the country's first black president. Even very successful movements have varying degrees of group cohesiveness and action over time (Stryker, Owens, and White 2000).

Some scholars may object to the characterisation of the WSM as a social movement because of its relatively small membership base. However, groups that require a high degree of trust due to the nature of their beliefs and activities have incentives to remain small and may have a higher than normal proclivity for ousting members who fall out of favour with the group (Bernstein 1997; Gamson 1997). This can be seen in religious sects as mainstream as Catholics or Methodists (Stark and Finke 2000). Size alone is not sufficient grounds for discounting movement status. Finally, a frequent complaint about social movements literature generally is that it tends to only study successful social movements; at worst, the WSM is unsuccessful at accomplishing meaningful social change. Lack of success does not violate movement status, and studying the WSM may add to the social movements literature because of the few studies of unsuccessful movements.

\section{White Aryan Resistance and Tom Metzger}

There are many groups of various sizes within the larger WSM, and they are active across the globe. Some groups have utilised these international connections in various ways (e.g., on the role of the internet for maintaining an international movement, Back 2002) - a topic deserving of its own study - but WAR has remained focused on a domestic strategy. As a guest author in one of its newsletters notes, 'WAR has often stated that you confine your activities to the US and urge other Americans to do the same, which is a sensible, sound policy in view of Europe's race laws' (An Irish Londoner 2001:6).

It is true that the international picture is made extremely complicated by varying national laws restricting WSM activity (Anti-Defamation League n.d.), and it is why my focus here is on the WSM in the United States. However, it is important to note that WAR's founder and leader Tom Metzger believes that these laws weaken 
both the scope and aspirations of the movement in other countries, making racially-aware whites in the United States superior to supremacists elsewhere, in his view. According to Metzger (2000:3), 'only a tiny minority are willing to sacrifice themselves in an attempt to stop [a non-white invasion] . . . there is no support from outside the country for any such action. Europe and Russia have their own problems.'

Precise goals and ideology may vary across groups of the WSM, but they have in common a belief in the superiority of the white race, a hatred for non-whites, and a desire for a socio-political environment where white men have exclusive power. WAR represents one of the more extreme groups in the WSM, and has been linked to a variety of racially motivated violence including the brutal murder of Ethiopian student Mulugeta Seraw in 1988 (Langer 2003), links to the 1995 Oklahoma City bombing (Stern 1996), the likely involvement in the 2005 attempted murder of District Court Judge Joan Lefkow (Southern Poverty Law Center 2005), and 2009 connections to and support for the shooter at Washington D.C.'s Holocaust Museum (Metzger 2009).

WAR should be understood as a largely Neo-Nazi group ${ }^{2}$ (Berlet and Vysotsky 2006; George and Wilcox 1996), which are typically considered to be newer groups, relative to the $\mathrm{Ku} \mathrm{Klux} \mathrm{Klan}(\mathrm{KKK})$, for example, with on-average younger members who admire Adolf Hitler, Nazi Germany, and its symbols; WAR's most recognised symbol is that of a large, snarling wolf whose pupils have been replaced by swastikas. As Chip Berlet and Stanislov Vysotsky (2006) note, WAR should be understood as a political, rather than religious or youth cultural group within the WSM, but their appeal to youth should not be overlooked. Most WAR members are between thirteen and twenty-five years old (Anti-Defamation League n.d.), and it is believed that many members join other WSM groups as they age out of groups like WAR (Hamm 1993). The young age and early indoctrination of WAR members is likely one factor that contributes to its violence.

Studying more problematic components of the WSM like WAR that have a proclivity for trying to effect social change through violent action - as opposed to groups that merely complain about similar issues - can lead to a better understanding of which WSM groups and actions should receive the most law enforcement attention. WAR's relative transparency through their distribution of items like the newsletters analysed here also allows for investigation of beliefs likely held by other WSM groups that are not as forthright or easily accessed. My claim is not that WAR's response to 9/11 necessarily represents how every WSM group reacted to this event, but rather that WAR's perspectives represent the WSM attitudes that are most socially problematic. Understanding the most problematic and violent components of the movement is critical for allocating law enforcement's limited resources.

WAR was started by Tom Metzger, who is now considered a demagogue of the entire WSM. Some argue that, for all practical purposes, Metzger and WAR are synonymous. This may be true, but Metzger's visibility and importance in the larger WSM are undeniable. His successes as well as failures have shaped how other groups in the movement have strategised, recruited, and mobilised members, and it is useful to understand more about his background due to his role as creator 
and editor of the newsletters. Metzger was born in 1938 in Indiana, and little is known about him until he was drafted into the United States Army following high school. Although he quickly achieved the rank of corporal, his stint in the military was brief (Anti-Defamation League 2002; Hamm 1993), and Metzger joined the John Birch Society ${ }^{3}$ soon after ending his army career in 1961.

Finding the Society less reactionary and violent than he desired, Metzger spent the next decade shifting his affiliation from one supremacist group to another until starting his own organisation called the White Brotherhood. This organisation was intended to be a kind of racist army that would perpetrate violent acts against minorities in California, where Metzger then resided. Apparently finding his Brotherhood ineffective, Metzger and his Brotherhood joined the Knights of the $\mathrm{Ku}$ Klux Klan, led by David Duke, in 1974. Only four years later, Metzger and Duke had a falling out: Metzger wanted to advocate and initiate violence against non-whites, while Duke was unwilling to do so (Hamm 1993). Metzger then established and led a group called the California Knights of the KKK, dabbled in politics, and served as a minister for a Christian Identity church. ${ }^{4}$ By 1980 , Metzger was facing pressure from both KKK leaders and mainstream politicians because of his extremist views. He changed the name of his organisation, first, in 1980 to the White American Political Association, and again in 1983 to White Aryan Resistance - WAR (ibid.). At the same time, he began to publish the newsletter analysed here, also titled WAR.

In 1988, Metzger's dream almost ended when three WAR adherents beat Mulugeta Seraw, an Ethiopian immigrant studying in the United States, to death and said their actions were a result of the victim's race. Metzger initially praised the actions of the murderers, and the Southern Poverty Law Center brought a wrongful death civil suit on behalf of Seraw's family against Metzger and his son John, who had become a notable WAR actor. The Metzgers chose to represent themselves at trial, and in 1990, a jury rendered a $\$ 12.5$ million verdict against them and WAR. To this day, the Metzger's wages are garnished as part of the settlement (Langer 2003).

The lawsuit certainly was a shock to the entire WSM, limited WAR's ability to be politically active, and likely sent many sympathisers underground. However, the verdict also heightened many WSM members' sympathy for Metzger and further aggravated their feelings of being unfairly treated by the criminal justice system and government generally. Despite the verdict, Metzger did not halt production of his newsletter, and it has been printed quarterly or monthly since its inception in 1983, although the current version is in electronic format and has been renamed The Insurgent. WAR as an organisation, while weakened following the civil verdict, is far from dead, and like many of its fellow WSM groups, has experienced a resurgence of interest and possibly membership in the wake of the economic downturn and election of the United States' first African-American president.

\section{Theoretical Background - Nationalism}

There are continuing debates about the nature and definition of nationalism. Some authors, for example, focus on nationalism's political nature (e.g., Gellner 1983), 
some highlight its cultural aspects (e.g., Hobsbawm 1992; Smith 1996), and others demonstrate how extreme forms of 'ultra-nationalism' may lead to violence to protect the interests of those in power (e.g., Billig 1989; Payne 1996:14). It is John Breuilly's definition of nationalism that I rely on here, because of its simultaneous attention to nationalism's political focus and its ability to recursively influence collective identity. Breuilly also recognises that not all constituents of a given nation may be content with its present form, and indicates that social actors can use identity-based nationalistic appeals in attempts to undermine and shift in their favour the power of the existing state. The definition is as follows:

'[N]ationalism'... refer[s] to political movements seeking or exercising state power and justifying such actions with ... political doctrine[s] built upon three basic assertions:

(a) There exists a nation with an explicit and peculiar character.

(b) The interests and values of this nation take priority over all other interests and values.

(c) The nation must be as independent as possible.

(Breuilly 1982:3)

First, WAR members are ideally seeking to co-opt state power - the power to define whites as Americans and others as not, while at the same time influencing other whites, including politicians, to agree with and enforce this definition. The degree of desired enforcement varies somewhat across subgroups of Neo-Nazis, and ranges from the yearning for a separate United White States within the current U.S. boundaries, to the total extermination of all non-whites presently in the country. WAR favours the latter (see, e.g., 'How can I help stop Blacks from taking America ... ? The answer is simple. Kill them all', WAR 2000b:4).

Second, WAR construes the United States' 'explicit and peculiar character' as founded, built, and civilised by whites, for whites. In its true form, they say, the United States is the paragon of intellectual, technological, and other advancement, but the greatness of the state has been hampered by the large numerical presence of non-whites. Third, WAR's stated key goal is the preservation of the white race. They believe that the presence of non-whites in the United States not only hampers the nation, but imminently threatens the very existence of whites because of interracial marriage and crime. Members say that the preservation of the race should be every white person's primary concern, and that it should take priority over individual or family concerns. In WAR's words, as included in a page of ideological statements that remain constant across newsletter issues, 'The great White Aryan race must be advanced and protected at all costs and above all other interests.' Fourth, and as part of the effort to both maintain the race and restore the ideal version of the state, WAR strongly opposes international cooperation, either in the form of the United Nations, or through international trade and labour exportation.

The extreme nature of WAR's ideal, racialised nation as explained above should be reminiscent of the distinction between civic and ethnic nations (Brubaker 1992). ${ }^{5}$ Citizenship status in civic nations is typically governed by the principle of 
jus soli. That is, individuals gain citizenship by being born within the physical boundaries of the state and by presumably ideologically supporting the nation's agreed upon moral and political principles regarding rights and responsibilities. For example, the United States is considered to be a civic nation whose citizens typically live within the physical geographical boundaries recognised as belonging to the state, and whose citizens are expected to uphold ideals such as freedom and equality, which are considered central to the nation's principles.

Conversely, legal membership in ethnic nations is determined solely by ancestry. An example of this is Germany in the eighteenth and nineteenth centuries. Individuals were not considered citizens of the German state merely because they were born within its boundaries - instead, they must have been born into families considered German by heredity, according to the principle of jus sanguinis. Similarly, children of immigrants could never have been considered truly German, and offspring of German families abroad would have been considered German even if they had never set foot within the boundaries demarcating the physical state.

However, while nations are often considered to be either civic or ethnic, clear-cut distinctions do not always exist. Some researchers argue, for example, that the United States cannot be considered a wholly civic nation because despite the shared rhetoric of equal opportunity, great economic and other disparities remain between the majority white population and minority non-white groups (Fenton 2006). Others emphasise that the civic-ethnic distinction should never be overly reified because the concepts should be understood as ideal types on opposite ends of a heuristic continuum (Zubrzycki 2002). Real nations, in other words, necessarily incorporate both political/civic and cultural/ethnic distinctions. In practice, the United States may thus be considered a largely civic nation, within which ethnic boundaries are often salient.

It is in this milieu that WAR operates. Members of this and other white supremacist groups are certainly aware of the civic myths of equality and diversity that permeate the current understanding of the United States as a nation. As members of the larger WSM, however, they interpret their own interpersonal interactions from an ethnicised standpoint, and desire an ethnic definition for the nation through their frequent expression of a belief that American citizenship should only be synonymous with whiteness.

Given WAR members' yearning for this idealised all-white state that works only for whites' perceived best interests, it is also useful to include Anderson's (2006) concept of imagined communities. 'Imagined communities' refers to those that exist largely in the collective mind of its members; they are the result of shared understandings of what a particular nation and its customs should be. Anderson intended for the concept of imagined communities to apply to existing nations, for even within these, it is impossible for members to know all other members of the nation, and the nation's degree of sovereignty and community may in reality differ from the shared image of those principles that its constituents hold.

In WAR's case, 'imagined' is a bit more literal than this, as their desired version of the state does not (and in fact, cannot) exist in reality. This does not, however, prevent WAR members from envisioning themselves as part of a larger collective 
of racially pure white people who want to be part of an all-white state that works to preserve white interests. Finally, Anderson privileged the role of printed media in facilitating communication and increasing the perceived bond among members of an imagined community. While WAR's newsletters serve this function, it should not be forgotten that there are also vast online networks that enable continual facilitation and reinforcement of white supremacists' sense of community (Adams and Roscigno 2005; Futrell and Simi 2004).

\section{Theoretical Background - WSM Literature}

Other WSM researchers have explored the roles that gender and especially masculinity play for recruitment to and involvement in the movement (Blee 2003; Ferber 1999). James $\mathrm{Aho}^{6}$ (1990) and Rory McVeigh (2009) are among the authors who privilege the role of economic and political anomie in understanding involvement in extremism. In Seymour Lipset and Earle Raab's (1978:155) reverse formulation of status loss called 'status preservatism', groups that are losing status - either concretely, in the form of economic status, or more diffusely in the form of social capital - attempt to maintain or regain this status by aligning themselves with groups that had prestige at some point in the past. Debra Oswald (2005) discusses how symbolic, as well as real, threats to identity can invoke prejudice and exclusionary behaviour.

White supremacist examples of this would perhaps be more clear-cut during the height of the Klan's popularity in the 1920s when racism was more socially acceptable and the Klan was seen as a visible, active, and powerful political group (McVeigh, Myers, and Sikkink 2004); however, modern white supremacist members still find identity support in joining groups that seek to re-affirm the value of whiteness ${ }^{7}$ even if those groups currently have less socio-political power. Other researchers (Adamson 2000; Olzak and Shanahan 2003) have illustrated how white solidarity and even violence, particularly among youth, can result from perceived threats to white dominance in a variety of arenas ranging from neighbourhoods and housing to local job opportunities. This again can be attributed to perceived status loss or relative deprivation to non-white groups, and is linked to the concept of ethnic competition as explained by Susan Olzak (1992).

Jessie Daniels' (1997) perspective essentially combines the gender and statusloss trains of thought by linking supremacist notions of white masculine identity to movement understandings of the nation, while discussing the role of fear of outsiders and loss of control. She indicates that the WSM's notion of the nation 'is synonymous with "whiteness" and working - or middle-class masculinity . . . [it] is fragmented and subsumed under "race" (Daniels 1997:36-37). However, she does not discuss how this notion of the nation relates to existing nationalism literature or the potential ability to anticipate future WSM action. Colin Flint (2004:171) discusses ethnic nationalism and diaspora with reference to WSM examples, and speculates that public condemnation of WSM violent activity may in fact reinforce and encourage further violence, rather than reduce it. I suggest this could occur because WSM activists interpret disapproval from officials or 
others who supposedly represent non-white interests as further support for their violent expressions of alienation. To my knowledge, this is the first attempt to empirically draw implications for WSM behaviour, as well as ideology, by evaluating change following a major socio-political event like 9/11. My work is intended to be a complement to that of the above authors.

\section{Data and Methods}

The internet's role in promulgating white supremacist ideology should not be underestimated (see, e.g., Daniels 2009); however, newsletters are a more appropriate data source than WAR's online content for this purpose. WAR's newsletters are targeted toward existing, subscribing members, who presumably agree with WAR's ideology, rather than a more ambivalent public accessing their website. Newsletters therefore reflect WAR's ideology in its purest form; ideology is not softened in an effort to make it more palatable for potential recruits who are not yet as extreme as existing WAR members, as is sometimes the case with online content. Additionally, in 2001, it appears that greater time and effort was consistently invested in the newsletters, as they had been continually produced for nearly twenty years, while online content was (and is) only sporadically updated.

The general format of the WAR newsletter consists of sixteen pages of writing and two or three fliers for racist T-shirts or jewellery. The front page is either a political cartoon or picture of a movement member or opponent, along with the contact information for WAR. An editorial by Tom Metzger is next, followed by a page of brief statements about WAR's standpoint on various issues. This page remains constant across all newsletters in the sample, and the statements on this page are the standard, 'party line' variety addressing fourteen different issues ranging from race to religion to economics. Next are 'letters to the editor' and Metzger's responses, then a page of 'news updates' that are blurbs of interest or continuations of questions directed to Metzger. Then are five pages with articles of various lengths, typically written by 'WAR associates', although occasionally one about some race-based conflict is taken directly from the Associated Press or another news agency.

Six pages of advertisements for racist stickers, racist literature, CDs, and videos with recorded racist radio shows or music, all of which may be purchased from WAR, follow. Advertisements for racist memorabilia are not included in the analysis because the items are almost identical across all issues in the sample, and are comprised lists of one hundred or more titles with no detail as to content. Finally, racist political cartoons are smattered throughout each newsletter, and these are included in the analysis because they are clearly visible, are very polarising, and typically relate directly back to the newsletter content.

I used a total of twenty-four monthly newsletters dating from September 2000 to October $2002^{8}$ in the analysis. Because of the small sample size, chi squared or other statistical tests lack power here. Instead, I first used an approach similar to semiotic clustering, a form of content analysis that strives for an understanding of the culture of the group being studied (Barley 1983; Feldman 1994; Manning 1987; Tavory and Swidler 2009) to verify which concepts merited qualitative 
investigation. I then proceeded to a discourse analysis of these key themes. Discourse analysis allows for a qualitative, contextual understanding of the text in question that is more nuanced than what content analysis alone can provide, and the newsletter quotations throughout this paper are representative of how the concepts are reflected throughout the sample.

\section{Nationalism}

It may be unsurprising that supremacist groups like WAR have a framework for understanding nationalism that is different from that of most Americans. However, understanding exactly how and why their understanding is different is useful for interpreting, and perhaps predicting, their response to events of national relevance. For example:

It is good to be proud of your country and its history, but your country is not your nation. Our Race is our Nation and the only nation we owe allegiance to. For if our Race ceases to exist it will not matter one iota what lands it resided in nor what it did while it was there.

(WAR 2000c:9)

This quote confirms how WAR desires an ethnic definition of the nation by seeing 'race' and 'nation' as synonymous and denying any importance of 'the land', or a country's physical boundaries. At the same time, it privileges race over any kind of governmental or other authority, much as Daniels (1997) claimed. More explicitly, a short article in the December 2001 newsletter reads:

'Country' means a place to visit.

'Nation' a people of common ancestry.

'Sovereignty' means a people's right to keep race and culture intact; a right to self-determination.

'America' once meant 'a people, a nation of common ancestry, practicing and defending the idea of self-determination'.

(Associate 2001b:9)

Clearly, the proposed definition of nationalism again demonstrates an ethnic interpretation of the nation. The definition of country shows 'nation' and 'country' are not synonymous, but this time the implication runs deeper and flippantly indicates that the idea of one's country has no visceral meaning for WAR members. The inclusion of sovereignty, whose definition is in contrast to WAR's claims that the white race is being overrun and controlled by other racial groups, is meant to highlight this perceived fact and the disenfranchisement WAR members feel. The past-tense definition of America reveals that WAR believes the United States no longer is a white nation, and is therefore no longer a nation at all.

Other selections indicate that WAR also does not view traditional symbols of the nation, such as the American flag, in the same way as most Americans. They say, for example, 'The flag of our race is the swastika. The red and blue of the Jew flag symbolizes the colors of the white race after being kicked and beaten by the 
fucking traitors in 'our" government' (Associate 2001c:5). Note the quotations around the word 'our', illustrating how WAR does not feel the government represents their interests, and note the use of the swastika as their racial-national symbol.

Few Americans seem to believe that the government intentionally works against their best interests as WAR members do, and most responded quite differently to the terror attacks. Following 9/11, the imagined community of patriotic Americans at least intensified, if not expanded, as many people from a variety of racial and ethnic backgrounds gained a heightened awareness of their status as Americans as a result of the attacks. This was amplified by extended media coverage that portrayed the terrorists as attacking all of 'us'. Along with this heightened awareness of collective 'Americanness', there was an almost immediate rise in patriotic sentiment demonstrated through greater numbers of American flags being displayed in homes and businesses across the country, for example (see Li and Brewer 2004).

\section{Arabs and 9/11}

There was also a substantial rise in anti-Arab sentiment after 9/11 when the public learned that men from the Middle East were responsible for the terror attacks (Oswald 2005). Barbara Perry (2003) has discussed how there was long-standing anti-Arab bias in the United States that only needed a polarising event to result in an outbreak of violence, particularly when national leaders implicitly condone such action. Daniel Christie (2006) has documented the large spike in anti-Arab hate crimes following the attacks. Importantly, other scholars (e.g., Shaheen 2000; Suad, D'Harlingue, and Wong 2008) have noted that many Americans conflate 'Arab' with 'Muslim', to the extent that anti-Arab and anti-Muslim sentiment should likely be considered equivalent; this is certainly true for WAR, as demonstrated in quotations below.

WAR's overall Arab message is somewhat convoluted: Arabs are non-white and therefore not accepted as equals, but at the same time, the actions of the Arab terrorists are lauded as exemplars of ideal action in the vein of lone wolfing advocated by the WSM.

I'm sorry (no, I suppose I'm not), but as a White person whose only goal is the survival of my race, I will not turn to support a government that is killing us just because some towel heads did what a white man should have done.

(Associate 2001c:5)

If a number of Muslims can create such havoc giving their lives for a cause, why aren't you doing more.

(Metzger 2002:8)

The perspective on 9/11 is clearer, as illustrated by two quotes from Tom Metzger:

[The prevalence of race mixing and inactive whites] is why I do not get excited at all when an Arab crashes a plane into the Center Of World Trade 
Centers or into the Policing Power Pentagon Center that will support the disease that is killing us at all costs.

(Metzger 2001b:2)

I am far more afraid of the Iron Heel Government than I am of any Middle Eastern Arab. None of my friends have ever been killed by an Arab, but several have been killed by agents of the Iron Heel.

(Metzger 2001c:2)

Taken altogether, these selections confirm that WAR members were little impacted by the events of $9 / 11$; because their ideal imagined community differs so much from the nation in reality, the terror attacks were not perceived as a personal affront to WAR constituents. Metzger explicitly says that he did not know anyone who was killed on that day, so does not care about the thousands who died. In fact, WAR as a whole sees the attacks as positive for two reasons: it was an attack on a government, on a nation that does not represent white interests, and it was a model for ideal action.

\section{Violence and Mobilisation}

WAR is no stranger to violence, and one of its most central ideologies is that of 'worse is better'. Metzger says he borrows this from Vladimir Lenin and means that the worse things become for more whites - the worse status loss they experience - the more likely they are to band together with WAR's cause and demand change. ${ }^{9}$ This perspective, of course, assumes that all whites would have the same racialised interpretation of harmful social events. Here is an instance where a WAR subscriber indicates that riots, illegal immigration, and general social disorder by non-whites will force more whites to racially-aware action:

I am of the opinion that it will only take one or possibly two really large terror attacks on the scale of $9 / 11$ to create chaos in this country. Starting in large, non-white majority areas, they will instantly seize any breakdown of order to rampage and pillage and thus force White men to act at last! Also, any breakdown of the border security will bring a million muds over the border all at once on a holiday scavenger hunt. That will send the dominoes falling.

(Associate 2002:4)

As a result of this 'worse is better' philosophy, it would have been reasonable to expect a shift to a more violent, action-based rhetoric in the newsletters following 9/11. Combined with increased out-group animosity among the general American public, this could also have led to a more potent and successful WSM.

In other words, many Americans who are not part of the WSM may nonetheless hold racist beliefs (Kinder and Sears 1981). These people had a clearly identified racial-cultural 'other' against whom they could direct their frustration after 9/11. It is possible that more people would have been accepting of some degree of racially-motivated violence after the terror attacks. Christie's (2006) work supports this, as does Figure 1, which shows the number of anti-Muslim (as a proxy 
Figure 1. Chart of Anti-Muslim Hate Crimes, 1995-2007

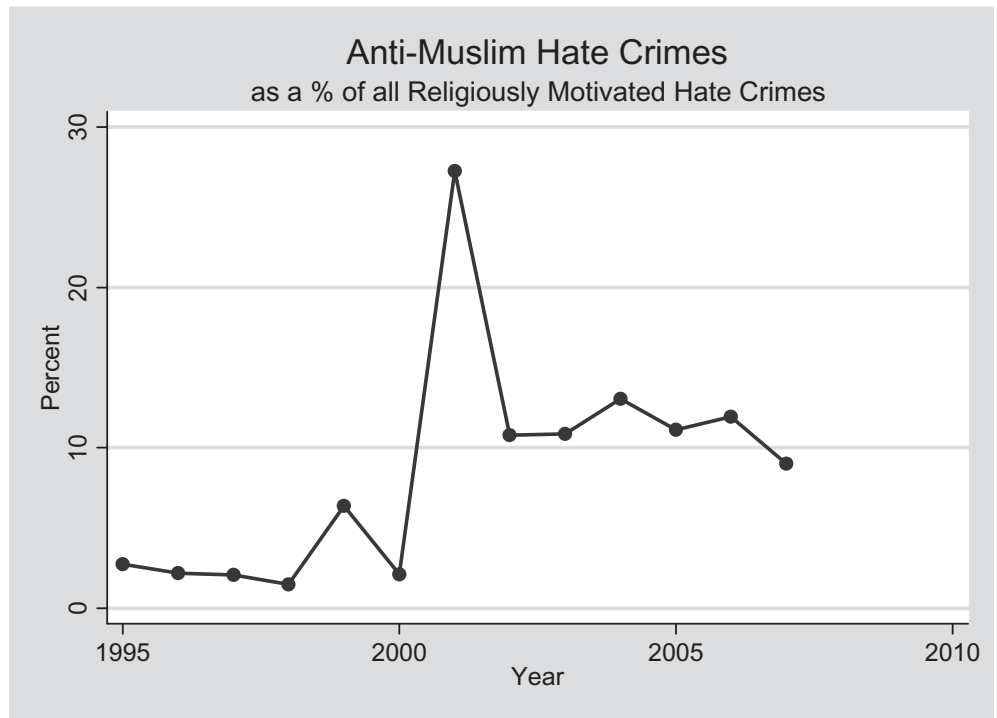

Source: FBI Uniform Crime Reports, http://www.fbi.gov/ucr/hatecm.htm\#bias (accessed April 2009).

for anti-Arab) hate crimes as a percent of all religion-motivated hate crimes from 1995 to 2007 . There is a jump of more than $25 \%$ in the year 2001 compared to the previous year.

\section{Blacks and Jews}

The content analysis revealed, however, that WAR did not take this approach. They neither advocated more violence, nor increased targeting of Arabs in their rhetoric. Instead, WAR largely continued targeting blacks and Jews. References to blacks are generally stereotypical slurs and dismissals of intellect or work ethic. Others laud contemporary examples from the news of whites, especially women, who had fended off black criminal offenders, and urge similar action, as in the following example.

White Power needs to be restored to America. I can't even walk in my own neighborhood without being scared of a mugging, shooting, or stabbing. I don't act like I hate Blacks around people or friends, only on the Internet. And I myself have been mugged three times and stabbed once and all three times it was done by Blacks.

(WAR 2000a:3)

More extreme entries yearn for the systematic lynching policies of the past in hopes of returning a sense of fear and race-based hierarchy to their communities.

Negative characterisations of Jews include stereotypical slurs and assessments of physical undesirability and greediness, but primarily rely on WAR's belief that 
Jewish elites control the government and work to undermine white authority and success.

As far as 'rag heads' being 'much worse than the average American Jew, how could they be? The Jews are much worse than any of our enemies (with the single exception of White race traitors) because they are wily and clever, and have enough intelligence and power to serve as the architects of our ultimate destruction, if we allow them to do so, ... [and will] demolish what little is left of Western civilization.

(Metzger 2001d:2)

As a rule, Jews produce nothing but take more than anyone else in society. They are dishonest and litigious too. Most lawyers are Jews. Nobody likes lawyers. Most of the people who own the banks are Jews. When was the last time you heard anyone tell you how happy he was with his bank's rates, account fees, extraneous charges, etc.

(WAR 2001:6)

These characterisations of Jews as powerful, smart, and financially secure are reflective of WAR members' sense of inferiority on these dimensions. They resent that social and political power, which has traditionally been embedded in male whiteness in the United States, seems to now be beyond their grasp. Perhaps surprisingly, there is not a single reference in the sample to the conspiracy theory that Jews were the masterminds behind the 9/11 attacks - a theory that was fairly prevalent among some in the general American population, as well as in Europe. Instead, WAR believes that Muslims initiated the attack because the United States generally supports Israel in Middle East conflicts.

Backing Israel, a group particularly on the outs with most of the civilized world, is proving highly hazardous to our health in this country. Now we have an entire complex of buildings leveled to the ground with thousands of dead people. Why? Because the U.S. decided to back the biggest bunch of parasites on the face of the planet: the Jews.

(Associate 2001a:5)

\section{Discussion}

WAR stuck with familiar out-group targets of blacks and Jews after 9/11 instead of shifting their focus to Arabs. These two groups were likely most salient in WAR members' daily lives (although this may now be different in 2011), but this consistency meant that WAR lost an opportunity to increase their membership and sympathisers. Does this mean that WAR was incapable of assessing the social climate for the benefit of the movement, as some research on the right-wing has claimed (e.g., Crenshaw 2000)?

Immediately after the attacks, and especially after the implementation of the Patriot Act in November 2001, the government's ability to monitor both individual and organisational communications and activities was greatly increased. Domestic hate groups like WAR were thought to receive particular attention, and this 
resultant climate of increased surveillance by and distrust of government likely made WAR members feel they were more distant than ever from their idealised all-white nation, as seen below.

The Congress and Senate are about to be given cart blanche to kick anyone's ass they don't like, especially White Separatists. Most will be so afraid when approached by Thought Police that all the years I have urged people to just say, I Have Nothing to Say, will go down the drain in a matter of seconds.

(Metzger 2001a:4, emphasis in original)

The reaction [to 9/11] will create a quick move toward an even greater police state, as the public demands the Iron Heel to protect them.

(Metzger 2001c:2)

These selections indicate that WAR believed the U.S. government was hostile toward white interests even prior to $9 / 11$, but believed the terror attacks would exacerbate this and lead to further fragmentation of the WSM. Further, WAR's 'worse is better' scenario had been achieved, at least for a time, when the terrorists successfully executed a plot that caused thousands of deaths and some degree of quotidian disruption for almost all Americans. WAR believed an appropriate level of terror or chaos had been enacted across the United States and saw little reason to encourage more of the same kind of action that would likely jeopardise their limited financial and membership resources.

An alternative explanation would be that WAR responded to the Patriot Act and increased surveillance with fear, rather than disdain. Under this explanation, WAR would have avoided mobilisation efforts to reduce the probability of facing popular criticism and legal scrutiny. However, praising violence as an ideal, efficacious tactic continued after $9 / 11$, as did rhetoric that was scornful of the government and its actions. The above quotations also indicate contempt for WSM members who are intimidated by governmental pressure, and there were no newsletter items after $9 / 11$ that suggested a shift to a more moderate or cautious ideology.

Self-censoring thus has less support as an explanation for WAR's lack of mobilisation after 9/11 than does resource preservation. Neither explanation would support the claim that right-wing groups are incapable of assessing social events for the benefit of the movement. Rather, it was a rational response within the context of an identity that is experienced as alienated from the nation.

\section{Conclusion}

The results here add to the existing knowledge on WSM groups in a few different ways. First, they provide a modification to Daniel's (1997) depiction of the WSM's understanding of nationalism: not only is it white and predominately male, but national inclusion is limited to those whites who are willing to take real, violent action to regain a white state. Second, the results demonstrate that the existing nationalism theories do not adequately account for the alienation and status loss experienced by WSM members. Without first understanding the strength and nature of diaspora WSM members have from an imagined, ethnic nation and the 
violent ends they advocate to achieve it, the nationalism literature would predict greater attitudinal and behavioural change from WSM members than what is seen here. Though Flint (2004) does discuss a feeling of diaspora among these groups, this article presents, to my knowledge, the first systematic analysis of how groups in the WSM respond to a major event and indicates that groups likely to be targets of WSM violence do not change much over time.

This consistency in targeted groups illustrates a need for increased attention to the kinds of groups WSM members have regular interactions with in order to predict future violent action. For example, a casual observer may have been completely surprised in the summer of 2009 by the shooting at the D.C. Holocaust Museum - a Jewish target. However, given what the results here indicate about WSM targets and sources of threat, an attack on a recognised, visible institution that represents Jewish and egalitarian interests is to be expected during a time of heightened economic stress and increased perceived racial threat due to the presence of the United States' first black president. Understanding this relatively fixed pattern of response should allow for better resource allocation in law enforcement and other groups that seek to limit the harm done by WSM groups.

Since 9/11, there was little activity or resurgence on the part of WSM groups in the United States until late 2008 and early 2009. Their self-imposed period of abeyance ended as the presence of a black First Family undoubtedly increased the salience of blacks in the lives of white supremacists and heightened their sense of status loss. There were several public incidents of 'non-racists' sending racist emails and other communications that were derogatory toward Obama and his family, and while 2008-2009 newsletters were not available at the time of this draft, chatter on racist websites was at an all-time high around the inauguration. We also witnessed the first real outbreak of violence perpetuated by WSM members in many years with the murder of an abortion doctor and the shooting at the D.C. museum. In the months and years ahead, it is in the best interest of law enforcement and academics alike to be mindful of the WSM's sense of status loss and understanding of the nation in an effort to anticipate and mitigate future violence.

\section{Notes}

${ }^{1}$ Some authors have distinguished between supremacist, separatist, and nationalist groups (e.g., Daniels 1997). I use the umbrella term 'supremacist' here because the notion that whites are superior to all other races is at the root of the supremacist and nationalist frameworks as well.

2 Sometimes WAR is referred to as a Skinhead group, and racist skinheads are often understood as a subset of Neo-Nazis that particularly lauds hate music (Daniels 1997; George and Wilcox 1996; Hamm 1993; Kaplan 2000). I prefer the broader term 'Neo-Nazi' because 'Skinhead' is now often a misnomer due to a push toward mainstream normativity; modern racists, even Skins, are frequently encouraged to not shave their heads, obtain stark racist tattoos, or participate in other visible signifiers of their racist identity in order to appear more 'normal' and blend in with mainstream society (see Cooter 2006).

3 The John Birch Society is a libertarian group that purportedly works to defend individual rights and the U.S. Constitution, but has multiple links to different racist organisations like the KKK (Lipset and Raab 1978). 
${ }^{4}$ Christian Identity claims whites are the true descendants of the biblical Adam, while the Jews are devious pretenders to the Israelite lineage who were spawned from a liaison between Eve and Satan (Walters 2000).

${ }^{5}$ For WAR, race, ethnicity, and culture are essentially synonymous.

${ }^{6}$ Aho also believes the role of religion is essential to right-wing involvement. Notably, WAR for the most part disdains religious, particularly Christian, participation because they believe it causes adherents to have an egalitarian, rather than racially-aware, outlook.

7 The goal of this paper is not to debate the definition of 'white' or 'whiteness', but it should be noted that these terms refer to socially constructed categories that have shifted over time (Garner 2007). Many social scientists are likewise concerned with reifying these social categories and the attendant, historical white dominance by studying whiteness or white supremacist groups without adequately fleshing out these concepts (Ferber 1999). However, as Brubaker and Cooper (2000:5) note, 'reification is a social process, not only an intellectual practice', and this project tries to understand the inner workings of a white supremacist group - similarly to Weber's Verstehen. It therefore takes as its starting point the understandings of racialised categories as defined by the group itself without addressing their correspondence to biological or social reality.

${ }^{8}$ Newsletters are not printed in January, so two additional, sequential issues are included to provide the full sample.

9 This ideology is distinct from, though similar to, another philosophy Metzger is known for advocating: the 'Third Position'. While ill-defined, supporting the Third Position amounts to believing that race-conscious whites should draw from the 'best' strategies of both the political right and left and resist both communism and capitalism as strategies designed to benefit Jews and other white enemies (Berlet and Lyons 2000). The Third Position may be understood as a further expression of the alienation WAR members feel from much of mainstream society and politics.

\section{References}

Adams, Josh and Vincent J. Roscigno. 2005. 'White Supremacists, Oppositional Culture and the World Wide Web'. Social Forces 84 (2): 759-78.

Adamson, Christopher. 2000. 'Defensive Localism in White and Black: A Comparative History of European-American and African-American Youth Gangs'. Ethnic and Racial Studies 23 (2): 272-98.

Aho, James A. 1990. The Politics of Righteousness: Idaho Christian Patriotism. Seattle: University of Washington Press.

An Irish Londoner. 2001. 'The Truth Will Set You Free'. WAR, 1 April: 6.

Anderson, Benedict. 2006. Imagined Communities: Reflections on the Origin and Spread of Nationalism. Rev. ed. New York: Verso.

Anti-Defamation League. N.d. 'The Skinhead International: A Worldwide Survey of NeoNazi Skinheads'. Skully Records. Available at: http://www.skullyrecords.com/ADL.htm (accessed 24 February 2005).

Anti-Defamation League. 2002. 'Tom Metzger/White Aryan Resistance'. Anti-Defamation League. Available at: http://www.adl.org/learn/ext_us/Metzger.asp?LEARN_Cat= Extremism\&LEARN_SubCat=Extremism_in_America\&xpicked=2\&item=7 (accessed 24 February 2005).

Associate. 2001a. 'Letters to the Editor'. WAR, 1 October: 5.

Associate. 2001b. 'Some Thoughts to Leave You With'. WAR, 1 December: 9.

Associate. 2001c. 'Wake Up Whitey!' WAR, 1 October: 5.

Associate. 2002. 'Terrible Tom'. WAR, 1 September: 4. 
Back, Les. 2002. 'Aryans Reading Adorno: Cyber-Culture and Twenty-First-Century Racism'. Ethnic and Racial Studies 25 (4): 628-51.

Barley, Stephen R. 1983. 'Semiotics and the Study of Occupational and Organizational Cultures'. Administrative Science Quarterly 28 (3): 393-413.

Berlet, Chip and Matthew N. Lyons. 2000. Right-Wing Populism in America: Too Close for Comfort. New York: Guilford Press.

Berlet, Chip and Stanislov Vysotsky. 2006. 'Overview of U.S. White Supremacist Groups'. Journal of Political and Military Sociology 34 (1): 11-48.

Bernstein, Mary. 1997. 'Celebration and Suppression: The Strategic Uses of Identity by the Lesbian and Gay Movement'. American Journal of Sociology 101 (3): 531-65.

Billig, Michael. 1989. 'The Extreme Right: Continuities in Anti-Semitic Conspiracy Theory in Post-War Europe'. In The Nature of the Right: European and American Politics and Political Thought since 1789, ed. Roger Eatwell and Noël O'Sullivan. London: Pinter.

Blee, Kathleen M. 2003. Inside Organized Racism: Women in the Hate Movement. Berkeley, CA: University of California Press.

Breuilly, John. 1982. Nationalism and the State. New York: St. Martin's Press.

Brubaker, Rogers. 1992. Citizenship and Nationhood in France and Germany. Cambridge, MA: Harvard University Press.

Brubaker, Rogers and Frederick Cooper. 2000. 'Beyond "Identity" ,. Theory and Society 29: 1-47.

Christie, Daniel J. 2006. '9/11 Aftershocks: An Analysis of Conditions Ripe for Hate Crimes'. In Collateral Damage: The Psychological Consequences of America's War on Terrorism, ed. Paul R. Kimmel and Chris E. Stout. Westport, CT: Praeger.

Cooter, Amy. 2006. 'Neo-Nazi Normalization: The Skinhead Movement and Integration into Normative Structures'. Sociological Inquiry 76 (2): 145-65.

Crenshaw, Martha. 2000. 'The Psychology of Terrorism: An Agenda for the 21st Century'. Political Psychology 21 (2): 405-20.

Daniels, Jessie. 1997. White Lies: Race, Class, Gender and Sexuality in White Supremacist Discourse. New York: Routledge.

Daniels, Jessie. 2009. Cyber Racism: White Supremacy Online and the New Attack on Civil Rights. Lanham, MD: Rowman \& Littlefield.

Feldman, Martha S. 1994. Strategies for Interpreting Qualitative Data. Newbury Park, CA: Sage.

Fenton, Steve. 2006. 'Race and the Nation'. In The SAGE Handbook of Nations and Nationalism, ed. Gerard Delanty and Krishnan Kumar. Thousand Oaks, CA: SAGE.

Ferber, Abby L. 1999. White Man Falling: Race, Gender, and White Supremacy. Lanham, MD: Rowman \& Littlefield.

Flint, Colin. 2004. 'United States Hegemony and the Construction of Racial Hatreds'. In Spaces of Hate: Geographies of Discrimination and Intolerance in the U.S.A., ed. Colin Flint. New York: Routledge.

Futrell, Robert and Pete Simi. 2004. 'Free Spaces, Collective Identity, and the Persistence of U.S. White Power Activism'. Social Problems 51 (1): 16-42.

Gamson, Joshua. 1997. 'Messages of Exclusion: Gender, Movements, and Symbolic Boundaries'. Gender \& Society 11 (2): 178-99.

Garner, Steve. 2007. Whiteness: An Introduction. New York: Routledge.

Gellner, Ernest. 1983. Nations and Nationalism. Ithaca, NY: Cornell University Press.

George, John and Laird Wilcox. 1996. American Extremists: Militias, Supremacists, Klansmen, Communists, and Others. Amherst, NY: Prometheus Books. 
Goodwin, Jeff and James M. Jasper. 2009. 'Editors' Introduction'. In The Social Movements Reader: Cases and Concepts, ed. Jeff Goodwin and James M. Jasper. 2nd ed. Oxford: Wiley-Blackwell.

Hamm, Mark S. 1993. American Skinheads: The Criminology and Control of Hate Crime. Westport, CT: Praeger.

Hobsbawm, E.J. 1992. Nations and Nationalism since 1780: Programme, Myth, Reality. Cambridge: Cambridge University Press.

Kaplan, Jeffrey, ed. 2000. Encyclopedia of White Power: A Sourcebook on the Radical Racist Right. Walnut Creek, CA: AltaMira Press.

Kinder, Donald R. and David O. Sears. 1981. 'Prejudice and Politics: Symbolic Racism versus Racial Threats to the Good Life'. Journal of Personality and Social Psychology 40 (3): 414-31.

Langer, Elinor. 2003. A Hundred Little Hitlers: The Death of a Black Man, the Trial of a White Racist, and the Rise of the Neo-Nazi Movement in America. New York: Metropolitan Books.

Li, Qiong and Marilynn B. Brewer. 2004. 'What Does It Mean to Be an American? Patriotism, Nationalism, and American Identity after 9/11'. Political Psychology 25 (5): 727-39.

Lipset, Seymour Martin and Earl Raab. 1978. The Politics of Unreason: Right Wing Extremism in America, 1790-1977. 2nd ed. Chicago, IL: University of Chicago Press.

Manning, Peter K. 1987. Semiotics and Fieldwork. Newbury Park, CA: Sage.

McVeigh, Rory. 2009. The Rise of the Ku Klux Klan: Right-Wing Movements and National Politics. Minneapolis, MN: University of Minnesota Press.

McVeigh, Rory, Daniel J. Myers, and David Sikkink. 2004. 'Corn, Klansmen, and Coolidge: Structure and Framing in Social Movements'. Social Forces 83 (2): 653-90.

Metzger, John. 2002. 'Whatever Happened to John Metzger?' WAR, 1 February: 8.

Metzger, Tom. 2000. 'Worse is Better'. WAR, 1 September: 3.

Metzger, Tom. 2001a. 'Editor's Note'. WAR, 1 November: 4.

Metzger, Tom. 2001b. 'Editorial'. WAR, 1 December: 2.

Metzger, Tom. 2001c. 'Editorial'. WAR, 1 October: 2.

Metzger, Tom. 2001d. 'Editorial'. WAR, 1 September: 2.

Metzger, Tom. 2009. 'Insurgent News and Views'. White Aryan Resistance. Available at: http://www.resist.com (accessed 12 June 2009).

Olzak, Susan. 1992. The Dynamics of Ethnic Competition and Conflict. Stanford, CA: Stanford University Press.

Olzak, Susan and Suzanne Shanahan. 2003. 'Racial Policy and Racial Conflict in the Urban United States, 1869-1924'. Social Forces 82 (2): 481-517.

Oswald, Debra L. 2005. 'Understanding Anti-Arab Reactions Post-9/11: The Role of Threats, Social Categories, and Personal Ideologies'. Journal of Applied Social Psychology 35 (9): 1775-99.

Payne, Stanley G. 1996. A History of Fascism, 1914-1945. New York: Routledge.

Perry, Barbara. 2003. 'Anti-Muslim Retaliatory Violence Following the 9/11 Terrorist Attacks'. In Hate and Bias Crime: A Reader, ed. Barbara Perry. New York: Routledge.

Shaheen, Jack G. 2000. 'Hollywood's Muslim Arabs'. The Muslim World 90: 22-42.

Smith, Anthony D. 1996. 'The Origins of Nations'. In Becoming National: A Reader, ed. Geoff Eley and Ronald Grigor Suny. New York: Oxford University Press.

Southern Poverty Law Center. 2005. 'Family of Judge Targeted by Hate Group Murdered'. Southern Poverty Law Center. Available at: http://www.splcenter.org/intel/news/ item.jsp?aid=11 (accessed 16 March 2006). 
Stark, Rodney and Roger Finke. 2000. 'Church-to-Sect Movements'. In Acts of Faith: Explaining the Human Side of Religion, ed. Rodney Stark and Roger Finke. Berkeley, CA: University of California Press.

Stern, Kenneth S. 1996. A Force Upon the Plain: The American Militia Movement and the Politics of Hate. New York: Simon \& Schuster.

Stryker, Sheldon, Timothy J. Owens, and Robert W. White, eds. 2000. Self, Identity, and Social Movements. Minneapolis, MN: University of Minnesota Press.

Suad, Joseph and Benjamin D'Harlingue, with Alvin Ka Hin Wong. 2008. 'Arab Americans and Muslim Americans in the New York Times, Before and After 9/11'. In Race and Arab Americans Before and After 9/11: From Invisible Citizens to Visible Subjects, ed. Amaney Jamal and Nadine Naber. Syracuse, NY: Syracuse University Press.

Tavory, Iddo and Ann Swidler. 2009. 'Condom Semiotics: Meaning and Condom Use in Rural Malawi’. American Sociological Review 74 (2): 171-89.

Walters, Jerome. 2000. One Aryan Nation under God: Exposing the New Racial Extremists. Cleveland, OH: Pilgrim Press.

WAR. 2000a. 'Letter to the Editor', 1 May: 3.

WAR. 2000b. 'Letter to the Editor', 1 September: 4.

WAR. 2000c. 'Part Two: An Interview With Richard Scutari, POW, The Order Bruders Schweigen', 1 December: 8-9.

WAR. 2001. 'I'm Not Your Brother', 1 November: 6.

Zubrzycki, Geneviève. 2002. 'The Classical Opposition between Civic and Ethnic Models of Nationhood: Ideology, Empirical Reality and Social Scientific Analysis'. Polish Sociological Review 139 (3): 275-95. 